\title{
Rozgraniczenie statutu rzeczowego i kontraktowego przy poszukiwaniu prawa właściwego do oceny zastrzeżenia prawa własności
}

\begin{abstract}
Retention of title as a security on tangible assets is well known in many legal systems. It enables to strengthen the position of the seller in such a contract of sale in which the payment of the price is agreed to be done later than the handing over the good. This instrument disturbs the traditional model of sale in two ways. Firstly, the conclusion of the contract is not directly followed - which takes usually place - by the performance of the obligation to transfer the property. Secondly, the right of property receives in that way a new role to play — it becomes a security right, guarantying the pecuniary claim of the seller and ceases the function of the principal right.

In order to find the law applicable to the retention of title, its different aspects - contractual and real - should be qualified according to their nature. These aspects should be treated separately and be assessed according to the proper legal system. For example, the law applicable to contractual assets of retention of title defines if such belated transfer of ownership affects any general rights and obligations of parties, such as the right to receive benefits from the asset or to bear costs of its maintenance. On the other hand, the law of actual location of the asset as a law applicable to real aspects of the retention of title defines the nature of the element disturbing the transfer of ownership and the scope of rights of the seller towards charged good as its owner.
\end{abstract}

Keywords: retention of title, retention of ownership, transfer of property, international interests in movables, private international law, law applicable to security rights in movables, international trade law

a) Dr, Uniwersytet Śląski w Katowicach. 


\section{Uwagi wstępne}

Zastrzeżenie prawa własności jest znane wielu systemom prawnym jako instrument pozwalający wzmocnić pozycję sprzedawcy w przypad$\mathrm{ku}$ sprzedaży dokonywanej z odroczonym terminem płatności, a więc w tych przypadkach, gdy wzajemne świadczenie kupującego ma nastapić $\mathrm{w}$ określonym $\mathrm{w}$ umowie terminie po wydaniu mu rzeczy ${ }^{1}$. Obok przewłaszczenia na zabezpieczenie (dopuszczalnego w mniejszej liczbie prawodawstw), pactum reservati domini stanowi jedna z postaci zabezpieczenia wierzytelności, których istota jest wykorzystanie w tym celu prawa własności, bez uciekania się do tworzenia odrębnego prawa o charakterze rzeczowym lub obligacyjnym. Podkreśla się przy tym, że będąc zabezpieczeniem tzw. kredytu kupieckiego zastrzeżenie prawa własności nie tyle służy zagwarantowaniu sprzedawcy szczególnej, uprzywilejowanej pozycji, ile ma na celu przywrócenie równowagi stron umowy wzajemnej w sytuacji, gdy strony postanowiły o niejednoczesnym spełnieniu swoich podstawowych świadczeń definiujących umowę sprzedaży². Omawiana konstrukcja prawna wprowadza więc do umowy sprzedaży zależność między zapłatą ceny a przeniesieniem prawa własności (lub też zależność między wynikającym z umowy sprzedaży obowiązkiem zapłaty ceny a prawnorzeczowym skutkiem umowy rozporządzajacej - w sytuacji, gdy umowa obligacyjna zgodnie z prawem właściwym nie rodzi podwójnego skutku), która nie powstaje w pozostałych przypadkach sprzedaży. Tym samym stanowiące essentialia negotii zobowiązania stron do zapłaty ceny oraz przeniesienia prawa własności stanowią narzędzie, pozwalajace zbudować zabezpieczajacy interesy stron mechanizm gwarancyjny, którego specyfika, polegajaca na zablokowaniu przeniesienia prawa własności, nie leży w szczególnych obowiązkach stron lub w nadaniu im nowej treści, lecz w ich wzajemnym powiąaniu ${ }^{3}$.

Można jedynie nadmienić, że omawiany instrument kojarzyć należy przede wszystkim z rzeczami ruchomymi. Z zakresu zastosowania

${ }_{1}^{1}$ Zob. J. Strauch: Der Eigentumsvorbehalt bei Warenlieferungen in das Ausland. Die Regelungen in wichtigen Exportländern. Offenbach am Main 1997. W książce tej autor przedstawił rozwiąania blisko 100 systemów prawnych, w których funkcjonuje zastrzeżenie prawa własności. Zob. też A. von Ziegler, Ch. Debattista, O. Plégat: Transfer of Ownership in International Trade. The Hague 2010.

${ }^{2}$ F. Pérochon: La réserve de priopriété dans la vente de meubles corporels. Paris 1988, s. 4; S. Sandoz: L’inscription du pacte de réserve de propriété: une solution „géniale”... diabolique. „Revue de droit Suisse” / „Zeitschrift für Schweizerisches Recht” 1987, 1, s. 543.

${ }^{3}$ F. Pérochon: La réserve..., s. 29. 
norm odnoszących się do zastrzeżenia prawa własności ustawodawcy lub orzecznictwo w poszczególnych systemach prawnych wyraźnie wyłączaja nieruchomości ${ }^{4}$.

Termin „zastrzeżenie prawa własności” jest zazwyczaj używany zarówno dla określenia porozumienia stron, którego treścia jest zablokowanie przejścia prawa własności na nabywcę aż do chwili spełnienia przesłanki, od której zależy takie przejście, jak też dla nazwania skutku takiego porozumienia. Pactum reservati domini w pierwszym z wyżej wskazanych znaczeń towarzyszy najczęściej umowie sprzedaży ${ }^{5}$, stanowiąc albo jedna z jej klauzul, albo też odrębna umowę, zawieraną z reguły w terminie późniejszym niż sprzedaż ${ }^{6}$. Jedynie w niektórych systemach prawnych dopuszcza się, aby sprzedawca, już po zawarciu umowy sprzedaży - o ile nie prowadzi ona do przeniesienia prawa własności mógł poczynić stosowne zastrzeżenie w drodze jednostronnego oświadczenia woli, na przykład w chwili wydania rzeczy?

W niewielu też systemach prawnych zezwala się, aby przesłanka, od której zależy przejście prawa własności ze sprzedawcy na kupującego, było spełnienie innego niż zapłata ceny świadczenia ${ }^{8}$. Z reguły z unormowań krajowych wynika, że do rozporządzenia dochodzi z chwilą zapłaty ceny, a $\mathrm{w}$ przypadku płatności dokonywanej $\mathrm{w}$ częściach $-\mathrm{z}$ chwilą zapłaty ostatniej raty. Słusznie więc zwraca się w literaturze uwagę, że w przypadku sprzedaży z zastrzeżeniem prawa własności dochodzi do zatarcia linii rozgraniczającej stosunek obligacyjny od rzeczowego, gdyż brak zapłaty ceny, stanowiący niewykonanie lub nienależyte wykonanie zobowiązania przez dłużnika, wywiera skutek w sferze prawnorzeczowej ${ }^{9}$.

${ }^{4}$ L. Aynès, in: Cours de droit civil. T. 9: Les sûretés. La publicité foncière. Eds. P. Malaurie, L. Aynès. Paris 2000, s. 316.

${ }_{5}^{5} \mathrm{Na}$ ogół nie budzi wątpliwości możliwość posłużenia się zastrzeżeniem prawa własności w odniesieniu do innej niż sprzedaż umowy mającej na celu przeniesienie własności. W prawie polskim zob. regulacje k.c. odnoszące się do umowy dostawy, kontraktacji czy też umowy o dzieło.

${ }^{6} \mathrm{~W}$ niektórych systemach prawnych wystarcza złożenie oświadczenia woli tylko przez aktualnego właściciela rzeczy (sprzedawcę).

7 S. Lißner, D. Zwernemann: Eigentumsvorbehalt im internationalen Handel. In: Handbuch für Kaufrecht. Rechtsdurchsetzung und Zahlungssicherung im Außenhandel. Hrsg. S.G. Häberle. München-Wien 2002, s. 299; J.W. Rutgers: International Reservation of Title Clauses. A study of Dutch, French and German International Law in the Light of European Law. The Hague 1999, s. 29.

${ }^{8}$ K.P. Heß: Der Eigentumsvorbehalt und die Sicherung von „all - sums - clauses” in englischen und schottischen Recht. „Recht des Internationalen Wirtschaft” 1991, H. 9, s. 768; Ch. Kessel: Eigentumsvorbehalt und Rezession in Grossbritannien. „Recht des Internationalen Wirtschaft" 1991, H. 10, s. 815.

9 A. Kunicki: Skutki prawne zastrzeżenia własności. „Ruch Prawniczy, Ekonomiczny i Socjologiczny" 1967, z. 2, s. 32. 
Zastrzeżenie prawa własności prowadzi więc do zakłócenia tradycyjnego modelu sprzedaży $\mathrm{w}$ dwóch aspektach ${ }^{10}$. Po pierwsze, dochodzi do rozdzielenia w czasie dwóch etapów, które w przypadku większości umów następują bezpośrednio po sobie: zawarcia umowy (połączonego często z przeniesieniem posiadania) oraz przejścia prawa własności na nabywcę $e^{11}$. Dzieje się tak dlatego, że skutek rozporządzający sprzedaży zostaje powiązany z okolicznością faktyczna, z definicji niepewna, w postaci zapłaty ceny ${ }^{12}$. Po drugie, prawo własności uzyskuje w ten sposób zupełnie nową funkcję, stając się zabezpieczeniem wierzytelności. Tym samym własność, definiowana we wszystkich podręcznikach prawa cywilnego jako prawo podstawowe i samoistne, przestaje być celem samym $\mathrm{w}$ sobie, przyjmując rolę służebną względem wierzytelności ${ }^{13}$. Co więcej, z punktu widzenia interesów kupującego nabycie prawa własności schodzi na dalszy plan, ustępując miejsca uzyskaniu upoważnienia do faktycznego korzystania z rzeczy. Odpowiada to funkcjonalistycznemu podejściu do instytucji prawnych, coraz częściej dominującemu w praktyce obrotu gospodarczego ${ }^{14}$.

Niemal powszechne dopuszczenie w poszczególnych systemach prawnych zastrzeżenia prawa własności, które pozwala uzależnić przeniesienie prawa własności od zapłaty ceny za nabywaną rzecz, jest jedna z przyczyn, które sprawiły, że ten rodzaj zabezpieczenia wierzytelności sprzedawcy jest dość chętnie stosowany w praktyce międzynarodowego obrotu handlowego ${ }^{15}$. Nie bez znaczenia pozostaje również znaczne odformalizowanie wymagań dotyczących skuteczności i ważności zastrzeżenia $\mathrm{w}$ większości prawodawstw, co wpływa na uproszczenie

10 A. Szpunar: Zastrzeżenie wtasności rzeczy sprzedanej. „Państwo i Prawo” 1993, z. 6, s. 30 .

11 E.M. Kieninger: Mobiliarsicherheiten in Europäischen Binnenmarkt. Baden-Baden 1996, s. 57; K. Naumann: Der Eigentumsvorbehalt im deutsch-italienischen Rechtsverkehr. Frankfurt am Main-Bern-Bruxelles-New York-Oxford-Wien 2001, s. 28.

12 Ta niepewność prowokuje niekiedy pytania o to, czy sprzedaż z zastrzė̇eniem prawa własności ma wciąż charakter czynności prawnej rozporządzającej. Zob. H. Al Dabb a gh: La clause de réserve de propriété dans les ventes mobilières à credit. Étude de droit comparé français et irakien. Aix-Marseille 2004, s. 27.

13 Ibidem.

${ }^{14}$ L. Aynès, in: Cours de droit civil..., s. 311.

${ }^{15}$ Ch. Bernstorff: Der Eigentumsvorbehalt in den EG-Staaten. „Recht der Internationalen Wirtschaft" 1993, H. 5, s. 366; I. Juvet: Des sûretés mobilières conventionelles en droit international privé. Bern-Franfurt am Main-New York-Paris 1990, s. 20; M. Schulz: Der Eigentumsvorbehalt in europäischen Rechtsordnungen. Rechtvergleichende Untersuchung des deutschen, englischen und französischen Rechts unter besonderer Berücksischtigung von Erweiterungen und Verlängerungen. Frankfurt am MainBern-New York-Paris-Wien 1998, s. 3. 
i przyspieszenie zawierania umów sprzedaży z odroczonym terminem płatności ${ }^{16}$.

Podejmowane dotychczas próby unifikacji materialnoprawnej regulacji zastrzeżenia prawa własności nie zakończyły się znaczącym sukcesem $^{17}$. Tym większą więc rolę przy ocenie treści i skutków zastrzeżonego prawa własności odgrywają zabiegi związane z poszukiwaniem prawa

${ }^{16}$ V. Ha se: Entwicklung der Verkäufersicherungsrechte an beweglichen Sachen in Frankreich. Frankfurt am Main 2001, s. 45; J. Marlow, D. Weber-Rey: Retention of title clauses in Germany. „International Company and Commercial Law Review” 1994, no. 5, s. 234; J.W. Rutgers: International Reservation..., s. 2.

${ }^{17}$ W szczególności wskazać należy na wypracowana pod auspicjami UNIDROIT Konwencję o międzynarodowych zabezpieczeniach na wyposażeniu ruchomym z $2001 \mathrm{r}$. wraz z towarzyszącymi jej Protokołami. Zob. m.in.: Ch. Chinkin, C. Kessedjian: The legal relationship between the proposed UNIDROIT Convention and its equipment specific Protocols. „Revue de droit uniforme”, „Uniform Law Review” 1999, 2, s. 3 i n.; B. Foëx: La réserve de propriété dans l'avant - projet de Convention d'UNIDROIT: un point de vue suisse. „Revue de droit uniforme”, „Uniform Law Review” 1999, 2, s. 413 i n.; S. Gopalan: Securing Mobile Assets: The Cape Town Convention and Its Aircraft Protocol. „North Carolina Journal of International Law and Commercial Regulation” 2003, vol. 29, s. 71 i n.; R. Goode: A Credit Law for Europe? „International and Comparative Law Quarterly" 1974, vol. 23, s. 227; Idem: The preliminary draft UNIDROIT Convention on International Interests in Moblie Equipment: the next stage, Revue de droit uniforme. „Uniform Law Review” 1999, no. 2, s. 209 i n.; Idem: The Cape Town Convention on International Interests in Mobile Equipment: a Driving Force for International Asset - Based Financing. „Revue de droit uniforme”, „Uniform Law Review” 2002, 1, s. 3 i n.; D.A. Panahy, R. Mittal: The prospective UNIDROIT Convention on international interests in mobile equipment as applied to space property. „Revue de droit uniforme”, „Uniform Law Review” 1999, 2, s. 304 i n.; H. Rosen: Creating an international security structure for railway rolling stock: an idea ahead of its time? „Revue de droit uniforme”, „Uniform Law Review” 1999, 2, s. 316 i n.

Z perspektywy Unii Europejskiej (wcześniej: Europejskiej Wspólnoty Gospodarczej) najistotniejsze w tej mierze znaczenie miały inicjatywy podejmowane przy opracowywaniu projektów dyrektyw o uznawaniu nieposesoryjnych zabezpieczeń na rzeczach ruchomych i klauzul skutkujacych zastrzeżeniem prawa własności w przypadku sprzedaży rzeczy ruchomych z 1973 r. (prace nad projektem zarzucono z uwagi na zbyt duże rozbieżności w odniesieniu do systemu rejestracji zabezpieczeń) oraz dyrektywy 2000/35/WE Parlamentu Europejskiego i Rady z dnia 29 czerwca 2000 r. o zwalczaniu opóźnień w transakcjach handlowych.

Zob. m.in.: R. Goode, U. Drobnig: Security for Payment in Export and Import Transactions. In: Commercial Operations in Europe. Eds. K. Simmonds, R. Goode. London 1978, s. 339 i n.; E.M. Kieninger, in: Security Rights in Movable Property in European Private Law. Ed. E.M. Kieninger. Cambridge 2004, s. 22; T.M. Margellos: La protéction du vendeur à crédit des objets mobilières à travers la clause de réserve de propriété (Etude de droit comparé). Paris 1989, s. 21; C. Mik, E. Wojtaszek-Mik: Zwalczanie opóznień $w$ płatnościach $w$ transakcjach handlowych $w$ świetle dyrektywy 2000/35/WE i prawa polskiego. "Zeszyty Prawnicze UKSW” 2000, z. 3, s. 228 i n.; J. Milo: Retention of Title in European Business Transactions. „Washburn Law Journal” 2003, vol. 3, s. 123 i n. 
właściwego. Wynika to stąd, że niezależnie od tego, iż pactum reservati domini jest zabezpieczeniem znanym większości systemów prawnych spotykane regulacje, a także praktyka stosowania przepisów normujących omawiane zabezpieczenie różnią się od siebie, niekiedy w dość znacznym stopniu. Różnice te powoduja, że zastrzeżenie prawa własności stosowane w zagranicznym obrocie handlowym bardzo często staje się źródłem całego wachlarza trudności kolizyjnoprawnych. Niniejsza wypowiedź poświęcona jest zasygnalizowaniu jedynie niektórych z nich.

\section{Trudności kwalifikacyjne ujawniające się przy kolizyjnoprawnej ocenie zastrzeżenia prawa własności}

Próba odszukania prawa, które mogłoby objać swą właściwością omawiana konstrukcję prawna, w pełni ujawnia znaczenie kwalifikacji rozgraniczającej ${ }^{18}$, służącej przeprowadzeniu linii demarkacyjnej pomiędzy zakresami miarodajnych norm kolizyjnych i wyznaczonych nimi statutów. Kolizyjnoprawna ocena zastrzeżenia prawa własności jako instrumentu sprzężonego $\mathrm{z}$ obligacyjnymi obowiązkami stron umowy sprzedaży, oddziałującego przy tym na najbardziej klasyczny skutek ${ }^{19}$ prawnorzeczowy tej umowy w postaci przeniesienia prawa własności, wymaga dokonania zabiegu pozwalajacego oddzielić od siebie te elementy analizowanego stosunku prawnego, które powinny być poddane, zgodnie ze swą natura, prawu właściwemu do oceny podmiotowych praw rzeczowych, od tych komponentów zastrzeżenia, które podlegają systemowi prawnemu adekwatnemu z punktu widzenia praw i obowiązków obligacyjnych. Nie sposób też nie wspomnieć, że w drodze kwalifikacji rozgraniczającej podlegają wyodrębnieniu (i poddaniu oddzielnie wskazanemu prawu właściwemu) również kwestie czastkowe w postaci formy umowy oraz zdolności stron ${ }^{20}$. Należy

${ }^{18} \mathrm{Na}$ temat kwalifikacji por. m.in. M. Pazdan: Prawo prywatne międzynarodowe. Warszawa 2017, s. 76 i n.; Idem, w: „System Prawa Prywatnego”. T. 20A: Prawo prywatne międzynarodowe. Red. M. Pazdan. Warszawa 2014, s. 303 i n., w tym uwagi odnoszace się do kwalifikacji rozgraniczającej na s. 318 - 323.

19 Należałoby podkreślić, że chodzi zarówno o prawnorzeczowy skutek umowy obligacyjnej w systemie prawnym hołdującym zasadzie podwójnego skutku umów zobowiązujących do dokonania rozporządzenia, jak i o odrębną umowę prawa rzeczowego wzorem niemieckiego BGB.

${ }^{20}$ D. Looschelders: Internationales Privatrecht. Art. 3-46 EGBGB. BerlinHeidelberg 2004, s. 33. 
także liczyć się z ingerencja prawa występującego w roli statutu majątkowych stosunków małżeńskich oraz statutu małżeńskiej umowy majatkowej, ustalonych na podstawie art. 51 p.p.m. lub art. 52 p.p.m. (wraz $\mathrm{z}$ ewentualna korektą wynikajaca $\mathrm{z}$ art. 53 p.p.m. ${ }^{21}$ ) w tych przypadkach, gdy co najmniej jeden z kontrahentów jest osobą fizyczną pozostająca w związku małżeńskim. Dalsze komplikacje mogą wynikać z ogłoszenia upadłości jednej ze stron umowy sprzedaży lub poddania się przez nią innego rodzaju procedurze, pozwalającej uzyskać ochronę przed wierzycielami. Wówczas wynikające z siły ciążenia statutu upadłościowego modyfikacje w ocenie ustanowionego zabezpieczenia moga dotyczyć w szczególności dopuszczalności i sposobu realizacji tego ostatniego. Nie jest też możliwe pominięcie prawa właściwego do oceny zabezpieczonej wierzytelności, które może m.in. oddziaływać zarówno na powstanie, jak i trwanie zabezpieczenia.

Kwalifikacja zastrzeżenia prawa własności nie jest więc zadaniem łatwym $^{22}$. Szczególną uwagę poświęcić należy zabiegom zmierzającym do odgraniczenia statutu rzeczowego od statutu obligacyjnego ${ }^{23}$. Konieczność taka wynika z tego, że - co już wspomniano powyżej - zarówno merytoryczne regulacje, jak i praktyka stosowania zastrzeżenia prawa własności w poszczególnych państwach charakteryzuja się tym, że sfera prawnorzeczowa i obligacyjna oddziałuja na siebie w znacznym stopniu, wzajemnie się zazębiając ${ }^{24}$. Okoliczność, że zastrzeżenie prawa własności zazwyczaj towarzyszy umowie zobowiazaniowej ${ }^{25}$ skutkuje komplikacjami w obrębie prawa prywatnego międzynarodowego, rodząc pytania

${ }^{21} \mathrm{Na}$ temat sposobu działania art. 53 p.p.m. i wprowadzonej przez tę normę korekty w zakresie zaciagania i wykonywania zobowiązań przez małżonka zob. m.in. A. Kozioł, J. Zrałek, w: „System Prawa Prywatnego”. T. 20C: Prawo prywatne międzynarodowe. Red. M. Pazdan. Warszawa 2015 oraz Iidem, w: Prawo prywatne międzynarodowe. Komentarz. Red. M. Pazdan. Warszawa 2018.

${ }^{22}$ Y. Loussouarn: Les conflits de lois en matière de réserve de propriété. In: Études offertes à Roger Houin. Problèmes d'actualité posés par les entreprises. Paris 1985, s. 275; Eadem: Les conflits de lois en matière de réserve de proprieté. Travaux du comité français de droit international privé. Séance du 18 mai 1983 sous présidence de Henri Batiffol. In: Droit International Privé, Années 1982-1983. Paris 1986, s. 91; P. Meyer: Les conflits de lois en matière de réserve de propriété après la loi du 12 mai 1980. La semaine juridique, Edition générale. Paris 1986, s. 6.

${ }^{23}$ A. Bonomi: Der Eigentumsvorbehalt in Österreich und Italien unter Berücksichtigung anderer europäicher Rechtssysteme. Eine rechtvergleichende und kollisionsrechtliche Untersuchung. Berlin 1993, s. 30; K. Naumann: Der Eigentumsvorbehalt..., s. 169.

${ }^{24}$ V. Haase: Entwicklung der Verkäufersicherungsrechte an beweglichen Sachen in Frankreich. Franfurt am Main 2001, s. 12.

${ }^{25}$ Pomijam tu przypadek, gdy do zastrzeżenia prawa własności dochodzi w umowie rozporządzającej, zawieranej w wykonaniu istniejącego zobowiązania do przeniesienia prawa własności. 
o nature prawną określonego uprawnienia lub obowiązu wynikającego z umowy bądź zastrzeżenia, a w konsekwencji o poddanie oceny tegoż uprawnienia lub obowiąku miarodajnemu statutowi. Jeszcze trudniej o rozstrzygnięcie $\mathrm{w}$ tych sytuacjach, gdy strony dokonały zastrzeżenia prawa własności wywierającego skutek jedynie inter partes ${ }^{26}$.

Mimo wspomnianych trudności, nie należy lekceważyć doniosłości prawidłowo przeprowadzonego rozgraniczenia zakresów konkurujących z sobą statutów. Można przypomnieć, że w prawie prywatnym międzynarodowym czyni się wyraźne rozróżnienie pomiędzy sferą praw rzeczowych a sfera zobowiązań, ustanawiajac odrębne normy kolizyjne, oparte na różnych kryteriach determinujących poszukiwanie prawa właściwe$\mathrm{go}^{27}$. Dość wspomnieć, że w obrębie stosunków zobowiązaniowych pierwszoplanową rolę odgrywa zasada swobody kontraktujacych stron, wyrażająca się najdobitniej w możliwości dokonania wyboru prawa, które ma być właściwe do oceny mającego powstać lub już istniejącego stosunku prawnego. Odnośnie do statutu rzeczowego można jedynie wspomnieć, że we wszystkich systemach prawnych pierwszoplanową rolę odgrywa kryterium miejsca położenia rzeczy ${ }^{28}$. Należy też zauważyć, że statuty zobowiązaniowy i rzeczowy moga, w zależności od konkretnej sytuacji, oznaczać jeden i ten sam porządek prawny albo dwa różne systemy prawne ${ }^{29}$.

\section{Odgraniczenie statutu rzeczowego od statutu obligacyjnego przy ocenie poszczególnych aspektów zastrzeżenia prawa własności}

Zakwalifikowanie poszczególnych elementów zastrzeżenia prawa własności do zakresu statutu rzeczowego bądź obligacyjnego wciąż budzi niemało wątpliwości w literaturze przedmiotu. Dające się uchwycić

${ }_{26}$ Tego rodzaju skutki może wywierać zastrzeżenie prawa własności, np. zgodnie z prawem włoskim lub polskim, w przypadku gdy strony nie zachowały wymaganej dla skuteczności erga omnes formy (wł. data certa, forma pisemna z data pewna).

${ }^{27}$ E. Drozd: Nabycie i utrata praw rzeczowych na rzeczy ruchomej w prawie prywatnym międzynarodowym (wpływ zmiany miejsca położenia rzeczy na właściwość prawa). Kraków 1977, s. 109.

28 J. Górecki, w: Komentarz do art. 41. W: Prawo prywatne międzynarodowe. Komentarz. Red. M. Pazdan [2018], s. 375 i n.

${ }^{29}$ J. Kosik: Zagadnienia prawa rzeczowego $w$ prawie prywatnym międzynarodowym z 1965 r. Warszawa-Wrocław 1967, s. 91. 
przy porównaniu poszczególnych wypowiedzi różnice mają najczęściej swe źródło w tradycji prawniczej, w której zakorzenione sa poglądy osoby dokonujacej oceny ${ }^{30}$. Wydaje się jednak uzasadnione przyjęcie jako zasady demarkacyjnej stwierdzenia, że statutem kontraktowym powinny być objęte te aspekty zastrzeżenia prawa własności, które oddziałują jedynie na relacje prawna łacząca strony umowy, natomiast do zakresu statutu rzeczowego zaliczyć można te elementy ocenianego stosunku i te jego skutki, które ujawniają się w odniesieniu do osób trzecich ${ }^{31}$.

Do zakresu statutu kontraktowego należy więc ocena, czy - a jeśli tak, to w jakim zakresie - w przypadku zastrzeżenia prawa własności modyfikacji podlegają ogólne zasady odnoszace się do sprzedaży. Może to dotyczyć w szczególności reguł mających za przedmiot koszty utrzymania rzeczy, pobieranie z niej pożytków ${ }^{32}$ czy też prawa i obowiązki stron związane z reżimem odpowiedzialności za jakość świadczenia sprzedawcy (rękojmią, gwarancją itp.).

Prawo występujace $\mathrm{w}$ roli statutu kontraktowego wypowiada się na temat prawa sprzedawcy do odstapienia od umowy w braku zapłaty przez kupującego ceny określonej w umowie. Ten sam system prawny decyduje o tym, czy w przypadku sprzedaży na raty przesłanką wystarczająca do odstąpienia od umowy jest opóźnienie w zapłacie jednej lub kilku rat, czy też konieczne jest, aby brak zapłaty w terminie dotyczył całej ceny. To prawo rozstrzyga też o tym, czy określenie przesłanek do odstapienia od umowy pozostaje w sferze swobody kontraktowej stron. W unormowaniach statutu kontraktowego należy również poszukiwać odpowiedzi na pytanie, czy sprzedawca, przy spełnieniu przesłanek określonych odpowiednimi przepisami lub umowa stron, a dotyczących niewykonania przez kupującego obowiązków wynikających z umowy sprzedaży, może żądać od kupującego wydania mu rzeczy przy utrzymaniu umowy sprzedaży w mocy (niem. Rücknahmeklausel). Jednakże przy ocenie prawnorzeczowych skutków odstąpienia decydujące znaczenie przyznać należy prawu wskazanemu norma kolizyjną z art. 41 p.p.m.

Zakresem statutu obligacyjnego objęte sa ponadto wszelkie zagadnienia związane z zapłatą ceny, stanowiącą przesłankę nabycia prawa

${ }^{30}$ Ibidem, s. 78, por. przytoczoną tam w przyp. 167 literaturę.

${ }^{31}$ I. Juvet: Des sûretés..., s. 30; K. Naumann: Der Eigentumsvorbehalt..., s. 169.

${ }^{32} \mathrm{O}$ ile samo uprawnienie do pobierania pożytków podlega ocenie w świetle norm statutu rzeczowego, o tyle należałoby przyjąć, że w przypadku gdy statut ten przewiduje, że wskutek zastrzeżenia prawa własności powstaje między kupującym a sprzedawca stosunek obligacyjny, który reguluje zasady używania rzeczy i pobierania z niej pożytków, wówczas stosunek ten (i wynikające z niego szczególne zasady odnoszące się do pożytków) podlega prawu występującemu w roli statutu kontraktowego. Zob. J. Górecki, w: Komentarz do art. $41 \ldots$, s. 390. 
własności. Tym samym prawo wybrane przez strony lub wskazane jedna z norm kolizyjnych rozporządzenia Rzym I decyduje m.in. o chwili i miejscu zapłaty, o sposobie zapłaty czy o dopuszczalności waloryzacji. Ten sam system prawny określa zasady odnoszace się do niewykonania zobowiązania pieniężnego w terminie. Jednak przy ustalaniu wysokości odsetek należnych z tytułu opóźnienia w zapłacie konieczne jest uwzględnienie stanowiska tego systemu prawnego, na mocy którego doszło do wykreowania określonego rodzaju pieniądza (prawo waluty) ${ }^{33}$.

Wady oświadczeń woli, które mogłyby się pojawić przy zawieraniu umowy skutkującej zastrzeżeniem prawa własności rzeczy sprzedanej, zgodnie z ogólna zasada, podlegaja prawu właściwemu do oceny tej czynności prawnej, której dotyczą ${ }^{34}$. Oznacza to, że w zależności od tego, jak kwalifikowany jest element zastrzeżenia, którego wada dotyczy, skutki określonej wady oświadczenia woli podlegaja badaniu w świetle norm systemu prawnego, który występuje odpowiednio w roli statutu kontraktowego bądź rzeczowego. Wydaje się, że w ten sam sposób należy traktować ewentualne nieporozumienia stron co do treści złożonych przez nie oświadczeń, mające swe źródło w posłużeniu się określonym językiem (niem. Sprachrisiko) ${ }^{35}$. Przy dokonywaniu interpretacji złożonych przez kontrahentów oświadczeń nie sposób nie odnieść się do prawa języka kontraktu, którym jest system prawny obowiązujący w państwie, którego językiem się posłużono ${ }^{36}$.

Statut rzeczowy rozstrzyga natomiast w pierwszej kolejności o przesłankach, od których zależne jest zablokowanie przeniesienia prawa własności ${ }^{37}$. Statut ten decyduje więc m.in. o tym, jakiego rodzaju czynność prawna (umowa czy też jednostronna czynność prawna sprzedawcy) może doprowadzić do zastrzeżenia prawa własności na rzecz sprzedawcy ${ }^{38}$ oraz o tym, czy czynność ta może być dokonana niezależnie od sprzedaży

${ }_{33}$ G. Żmij: Prawo waluty. Kraków 2012, s. 127.

${ }^{34}$ M. Pazdan: Prawo prywatne międzynarodowe. Komentarz. Red. M. Pazdan [2018]..., s. 169.

${ }^{35}$ K. Naumann: Der Eigentumsvorbehalt..., s. 169; M. Pazdan: Język kontraktu - jego znaczenie $i$ wyznaczanie. „Problemy Prawne Handlu Zagranicznego” 1988, T. 12, s. 35 .

${ }^{36}$ M. Pazdan: Prawo prywatne międzynarodowe. Komentarz. Red. M. Pazdan [2018]..., s. 228 .

${ }^{37}$ F. Pérochon: La réserve de propriété dans la vente de meubles corporels. Paris 1988, s. 2 i n.; J. Kosik: Zagadnienia prawa rzeczowego..., s. 91; M.J. Maaß: Die Gesischte des Eigentumsvorbehaltes, insbesondere im 18. und 19. Jahrhundert. Frankfurt am Main 2000, s. 38.

${ }^{38}$ S. Lißner, D. Zwernemann: Eigentumsvorbehalt im internationalen..., s. 209; J. Mestre, M.-E. Pancrazi: Droit Commercial. Droit interne et aspects de droit international. Paris 2009, s. 760. 
(m.in. w zawartej uprzednio umowie ramowej określającej zasady współpracy handlowej stron lub po zawarciu umowy sprzedaży, np. przy wydaniu rzeczy) ${ }^{39}$. Prawo właściwe, ustalone zgodnie z normą z art. 41 p.p.m., definiuje też najpóźniejszą chwilę, w której dokonanie zastrzeżenia wywrze pożądany skutek (chwila zawarcia umowy, chwila wydania rzeczy). Natomiast jeżeli dla ważności zastrzeżenia lub jego skuteczności wobec osób trzecich wymagane jest zachowanie odpowiedniej formy (np. znanej prawu polskiemu i włoskiemu daty pewnej, data certa), to konieczne wymagania formalne regulowane sa prawem wskazanym norma kolizyjna z art. 25 p.p.m. Innymi słowy, o tym, czy do zastrzeżenia prawa własności niezbędne jest zachowanie określonej formy czynności prawnej, moca której ma dojść do zastrzeżenia, oraz o skutkach niedochowania formy rozstrzyga prawo występujące $\mathrm{w}$ roli statutu rzeczowego ${ }^{40}$. Z kolei do zakresu statutu formy należy doprecyzowanie, jakich aktów staranności strony musza dochować, aby przesłanka zachowania określonej formy została spełniona ${ }^{41}$. Nie można przy tym tracić z pola widzenia sytuacji, w której dochodzi do zmiany statutu, a więc do zmiany okoliczności faktycznych decydujących o właściwości prawa określonych w łączniku normy kolizyjnej, jeszcze przed dojściem zastrzeżenia do skutku. Wówczas niezbędna może okazać się ocena dochowanej przez strony formy w świetle zasad odnoszących się do ekwiwalentności i substytucji formy, a w niektórych przypadkach - posłużenie się zabiegiem dostosowania.

Wśród przesłanek skuteczności zastrzeżenia prawa własności wobec osób trzecich (o tyle, o ile prawo właściwe, odgrywające rolę statutu rzeczowego, dopuszcza obok zastrzeżenia skutecznego erga omnes również postać zabezpieczenia wywołującego skutki jedynie inter partes), oprócz wspomnianej już formy szczególnej, w poszczególnych regulacjach materialnoprawnych spotyka się inne wymagania, służące najczęściej zapewnieniu jawności ustanowionego zabezpieczenia (niem. Publizität, ang. publicity, fr. publicité). Niekiedy wymagania te sprowadzają się do obowiązku kupującego do wyodrębnienia rzeczy, co do której (co do których — gdy przedmiotem sprzedaży jest większa liczba rzeczy oznaczonych co

${ }^{39}$ S. Lißner, D. Zwernemann: Eigentumsvorbehalt im internationalen..., s. 308; J.W. Rutgers: International Reservation..., s. 65; U. Spellenberg: Eigentumsvorbehalt in Frankreich. "Zeitschrift für Rechtsvergleichung, Internationales Privatrecht und Europarecht" 1994, H. 3, s. 129; R. Storp: Eigentumsvorbehalt und Aussonderungsverfahren nach der Reform des französichen Insolvenzrecht. „Recht des Internationalen Wirkschaft" 1996, H. 6, s. 464.

${ }^{40}$ R. Reisinger: Der Eigentumsvorbehalt im österreichischen und englischen Recht unter Berücksichtigung des österrichischen und englischen Kollisionsrechtes und der internationalen Zuständigkeit. Wien 2002, s. 84.

41 J. Pazdan: Komentarz do art. 25. W: Prawo prywatne międzynarodowe. Komentarz. Red. M. Pazdan [2018], s. 285. 
do gatunku) zastrzeżono prawo własności, z masy majątkowej kupującego oraz jej (ich) specjalne oznaczenie. W niektórych systemach prawnych zapewnieniu jawności ciążącego na rzeczy obciążenia służy publiczny rejestr ${ }^{42}$. W takim przypadku o materialnoprawnych następstwach wpisu do rejestru (m.in. o skutecznym zastrzeżeniu prawa własności, o uzyskaniu skuteczności erga omnes) rozstrzyga prawo miejsca aktualnego położenia rzeczy (art. 41 p.p.m. $)^{43}$. Jednakże o sposobie dokonywania wpisów, wymaganych dokumentach oraz o organizacji rejestru decyduje prawo (procesowe) państwa, w którym rejestr jest prowadzony ${ }^{44}$.

Prawo występujące w roli statutu rzeczowego odpowiada również na pytanie o rodzaj i sposób działania mechanizmu pozwalającego zablokować rozporządzenie rzeczą ${ }^{45}$. Prawo to rozstrzyga więc o tym, czy sytuacja prawna stron umowy sprzedaży ukształtowana jest na przykład z wykorzystaniem konstrukcji warunku (w tym przypadku wskazany łącznikiem rei sitae system prawny decyduje również o tym, czy jest to warunek zawieszający, czy rozwiąujaccy), terminu czy prawa odstąpienia. $\mathrm{Na}$ podstawie norm tego samego systemu prawnego należy też badać, czy stronom umowy sprzedaży przysługuje swoboda pozwalajaca na wybór jednego z dostępnych rozwiązań, czy też kontrahenci związani są bezwzględnie wiążącymi regulacjami. Jednakże występujące w roli instrumentu blokującego przeniesienie prawa własności konstrukcje prawne podlegają odrębnemu statutowi, miarodajnemu ze względu na ich naturę.

Właściwe prawo, wyznaczone normą kolizyjna z art. 41 p.p.m., pozwala ponadto ustalić, jakiego rodzaju przedmioty moga być obciążane zastrzeżeniem, a w szczególności czy dopuszczalne jest zabezpieczenie w ten sposób wierzytelności o zapłatę ceny za przenoszone prawo. Również rozróżnienie pomiędzy rzeczami ruchomymi a nieruchomościami (co jest istotne $\mathrm{w}$ przypadku, gdy prawo właściwe dopuszcza zastrzeżenie prawa własności jedynie w odniesieniu do ruchomości) dokonywane być powinno na podstawie przepisów prawa miejsca aktualnego położenia rzeczy ${ }^{46}$.

Normy statutu rzeczowego tradycyjnie rozstrzygaja też o pierwszeństwie praw rzeczowych obciążających jedną rzecz ${ }^{47}$. Zasadę tę należy odnieść odpowiednio do zastrzeżenia prawa własności. Nawet bowiem

${ }^{42}$ E.M. Kieninger: Mobiliarsicherheiten..., s. 59.

${ }^{43}$ M. Podhorecka: Skutki prawne zastrzeżenia prawa własności w obrocie międzynarodowym. Wybrane zagadnienia. „Kwartalnik Prawa Prywatnego” 2006, z. 1, s. 145; S. Sandoz: L’inscription du pacte de réserve de propriété..., s. 543.

${ }^{44}$ J. Górecki, w: Komentarz do art. 41..., s. 389; I. Juvet: Des sûretés..., s. 16.

${ }^{45}$ Zob. m.in. H. Al Dabbagh: La clause..., s. 44; J. Ghestin: Réflections..., s. 2 i n.

${ }^{46}$ E. Drozd: Nabycie i utrata praw rzeczowych..., s. 9; J. Górecki, w: Komentarz do art. $41 \ldots$, s. $380-381$.

${ }^{47}$ E. Drozd: Nabycie i utrata praw rzeczowych..., s. 100; J. Górecki, w: Komentarz do art. $41 \ldots$, s. 384. 
w systemach prawnych, w których zastrzeżenie nie przybiera postaci ograniczonego prawa rzeczowego, może powstać konflikt pomiędzy uprawnieniami: kupującego korzystającego z rzeczy przed nabyciem prawa własności oraz osoby, której przysługuje ograniczone prawo rzeczowe. Wówczas o tym, kto może w pierwszej kolejności wykonywać swoje prawo, decyduja regulacje obowiązujące $\mathrm{w}$ miejscu aktualnego położenia obciążonej rzeczy (art. 41 p.p.m.).

Również w świetle prawa występujacego w roli statutu rzeczowego rozstrzygać należy o zakresie uprawnień sprzedawcy jako właściciela sprzedanej rzeczy. W szczególności odnosi się to do określenia, czy sprzedawca może - a jeśli tak, to w jakich sytuacjach — występować z powództwem windykacyjnym wobec kupującego. Prawo wskazane normą kolizyjna z art. 41 p.p.m. wypowiada się ponadto w przedmiocie dopuszczalności przeniesienia analizowanego zabezpieczenia na osobę trzecia, a w przypadku pozytywnego stanowiska - definiuje przesłanki takiego przeniesienia, w szczególności rozstrzygając o tym, czy można przenieść zastrzeżone prawo własności bez jednoczesnego przelania wierzytelności, która to ostatnie prawo zabezpiecza ${ }^{48}$. Natomiast o wpływie przelewu wierzytelności bez przeniesienia zastrzeżonego prawa własności na dalsze trwanie zastrzeżenia rozstrzygać powinno prawo właściwe do oceny skutków przelewu.

Trudności nastręcza zakwalifikowanie uprawnienia kupującego do władania rzeczą i jej używania. Nie brak wypowiedzi, zgodnie z którymi zagadnienie to należy zaliczyć do statutu obligacyjnego ${ }^{49}$. Przemawiać by za tym miała okoliczność, że w wielu systemach prawnych przepisy je regulujace mają charakter dyspozytywny. Wydaje się jednak, że jest to pogląd błędny i należałoby opowiedzieć się za właściwością prawa wskazanego normą kolizyjną z art. 41 p.p.m. Nie ulega przecież wattpliwości, że uprawnienie do władania rzeczą i jej używania (jeżeli zgodnie z prawem właściwym przysługuje kupujacemu) wynika ze szczególnej sytuacji prawnorzeczowej, która docelowo ma prowadzić do nabycia przez kupującego prawa własności. Uprawnienie kupującego może być kształtowane przez normy statutu rzeczowego na wzór prawa obligacyjnego (np. użyczenia, najmu) lub rzeczowego (użytkowanie). W obu tych przypadkach prawo ustalone zgodnie z art. 41 p.p.m. rozstrzyga o swobodzie stron w kształtowaniu treści sytuacji prawnej kupującego, w tym o dopuszczalności upoważnienia tego ostatniego do dalszej sprzedaży rzeczy lub jej przetworzenia.

${ }^{48}$ I. Juvet: Des sûretés..., s. 30; K. Naumann: Der Eigentumsvorbehalt..., s. 31.

${ }^{49}$ G. Khairallah: Les sûretés mobilières en droit international privé. Paris 1984, s. 181; E.M. Kieninger: Mobiliarsicherheiten..., s. 215; K. Naumann: Der Eigentumsvorbehalt..., s. 169. 
Normy statutu rzeczowego decydują również o tym, komu — sprzedawcy czy kupującemu - przysługuje prawo do pobierania pożytków przed przejściem prawa własności na kupującego ${ }^{50}$.

System prawny wskazany norma kolizyjna z art. 41 p.p.m. wypowiada się $\mathrm{w}$ przedmiocie ochrony sytuacji prawnej kupującego niebędącego jeszcze właścicielem. W szczególności regulacje tego systemu decydują, czy kupującemu - a jeśli tak, to przy spełnieniu jakich przesłanek przysługuje roszczenie windykacyjne i negatoryjne, w tym również przeciwko sprzedawcy.

Do zakresu statutu rzeczowego wypada wreszcie zaliczyć przysługujace sprzedawcy roszczenia, wynikajace $\mathrm{z}$ odstapienia od umowy, których źródłem jest korzystanie z rzeczy przez kupującego i jej zużycie ${ }^{51}$. To samo prawo określa kryteria oceny, jakiej powinien być poddawany stopień zużycia czy zniszczenia rzeczy.

Kolejne wątpliwości pojawiają się przy ocenie przejścia ryzyka przypadkowej utraty rzeczy ${ }^{52}$. Choć w większości systemów prawnych przyjmuje się, że ryzyko przechodzi na nabywcę z chwila, w której staje się on właścicielem rzeczy, to należy pamiętać, że jest to najczęściej reguła dyspozytywna. Jedynie w prawie francuskim zasada ta nie może zostać wyłączona mocą umowy stron. Z tego też względu często wskazuje się, że w przypadku sprzedaży międzynarodowej aspekt ten podlegać ma statutowi rzeczowemu. Jednak po dłuższej analizie pogląd ten nie wydaje się trafny. Trzeba bowiem mieć na uwadze, że przejście ryzyka przypadkowej utraty rzeczy nie wywiera wpływu na sytuację osób trzecich. Co więcej, nie we wszystkich systemach prawnych chwila ryzyka przypadkowej utraty rzeczy została powiązana z chwilą przejścia własności, a w większości porządków prawnych to powiązanie nie ma charakteru bezwzględnie wiążącego. $\mathrm{Z}$ tych też względów można powyższe zagadnienie pozostawić regulacji norm statutu kontraktowego.

Można zasygnalizować, że niekiedy w rozważaniach dotyczących zastrzeżenia prawa własności rezygnuje się z prób przypisania poszczególnych aspektów zastrzeżenia prawa własności odrębnym statutom, wskazując, że stosowanie dwóch różnych systemów prawnych (o ile normy wskazujace prawo właściwe do sfery obligacyjnej oraz art. 41 p.p.m. prowadzą do właściwości dwóch systemów prawnych) prowadzić może do rezultatów trudnych do pogodzenia, a w efekcie do uniemożliwienia sprzedawcy zaspokojenia się z przedmiotu zabezpieczenia. Konieczność stosowania norm pochodzacych z różnych systemów prawnych do oceny

\footnotetext{
50 J. Górecki, w: Komentarz do art. 41..., s. 390. Zob. też przyp. 32.

${ }^{51}$ A. Bonomi: Der Eigentumsvorbehalt in Österreich..., s. 30.

${ }^{52}$ Ibidem, s. 48.
} 
instrumentu stanowiącego całość w sensie gospodarczym, choć łączącego $\mathrm{w}$ sobie elementy o niejednorodnym (rzeczowym i obligacyjnym) charakterze, może bowiem doprowadzić do wzajemnego wyłączenia się mechanizmów mających chronić sprzedawcę. Nieprzewidywalność rozstrzygnięć wynikających z trudnej do rozgraniczenia kolizji praw i związana z tym niepewność co do sytuacji prawnej wierzyciela skłaniają więc niektórych autorów do opowiedzenia się za dominacją jednego ze statutów, którego zakres zastosowania miałby rozciagać się na wszystkie zagadnienia związane z zastrzeżeniem prawa własności ${ }^{53}$. Stanowisko takie wydaje sie jednak trudne do akceptacji, a wspomniane wyżej przeciwności wynikające ze stosowania dwóch różnych systemów prawnych mogą zostać przezwyciężone $\mathrm{w}$ drodze dostosowania ${ }^{54}$.

Poza zakresem problemów kwalifikacyjnych pozostaje zagadnienie, które ma wprawdzie związek ze wzajemnym oddziaływaniem na siebie sfery obligacyjnej i rzeczowej, lecz dotyczy odmienności między systemami prawnymi opartymi na zasadzie podwójnego skutku w dziedzinie umów przysparzających a tymi, które przyjmuja w tej mierze rozwiązanie przewidujące konieczność dokonania dwóch odrębnych czynności prawnych. Chodzi mianowicie o zapewnienie automatyzmu przejścia prawa własności w przypadku spełnienia warunku w sytuacji, gdy stanowisko systemów prawnych występujących w roli statutów rzeczowego i obligacyjnego jest odmienne $\mathrm{w}$ odniesieniu do mechanizmu przeniesienia własności w zakresie dopuszczenia czynności prawnych o podwójnym skutku. Problematyka ta wykracza już jednak poza ramy niniejszego opracowania.

\section{Uwagi końcowe}

Zastrzeżenie prawa własności należy do tych instytucji prawa prywatnego, które przysparzają wiele trudności w ich ocenie. Przyczyną tego jest dwoista natura tego rodzaju prawa zabezpieczajacego - nie tylko ingeruje ono w mechanizm przeniesienia prawa własności, lecz rów-

${ }^{53}$ Ibidem, s. 30; I. Juvet: Des sûretés..., s. 30; K. Naumann: Der Eigentumsvorbehalt..., s. 31 .

${ }^{54} \mathrm{Na}$ temat dostosowania $\mathrm{w}$ polskim prawie prywatnym międzynarodowym zob. m.in.: M. Pazdan: Prawo prywatne międzynarodowe [2017], s. 86; K. Sznajder-Peroń, w: „System Prawa Prywatnego”. T. 20A: Prawo prywatne międzynarodowe. Red. M. Pazdan..., s. 537 i n.; Eadem, w: Prawo prywatne międzynarodowe. Komentarz. Red. M. Pazdan [2018], s. 74 i n. 
nież wywiera wpływ na sposób ukształtowania praw i obowiązków stron na płaszczyźnie obligacyjnej. Wspomniane trudności ze szczególną moca ujawniaja się przy poszukiwaniu prawa właściwego. Niezbędne jest odrębne badanie każdego uprawnienia i obowiązku związanego z oceniana instytucją w celu ustalenia, czy należy zakwalifikować go do zakresu statutu rzeczowego, czy kontraktowego. W ten sposób, przy ocenie różnych aspektów tego samego zagadnienia, do głosu mogą dochodzić różne systemy prawne, co z kolei każe stawiać pytanie o sposoby przezwyciężenia komplikacji wynikłych ze stosowania nieprzystających do siebie norm materialnoprawnych pochodzacych $\mathrm{z}$ dwóch prawodawstw. To ostatnie zagadnienie pozostaje jednak poza zakresem niniejszego opracowania.

\section{Bibliografia}

Ay nès L., in: Cours de droit civil. T. 9: Les sûretés. La publicité foncière. Eds. P. Malaurie, L. Aynès. Paris 2000.

Al Dabbagh H.: La clause de réserve de propriété dans les ventes mobilières à credit. Étude de droit comparé français et irakien. Aix-Marseille 2004.

Bernstorff Ch.: Der Eigentumsvorbehalt in den EG-Staaten. „Recht der Internationalen Wirtschaft" 1993, H. 5.

Bonomi A.: Der Eigentumsvorbehalt in Österreich und Italien unter Berücksichtigung anderer europäicher Rechtssysteme. Eine rechtvergleichende und kollisionsrechtliche Untersuchung. Berlin 1993.

Chinki E.Ch., Kessedjian C.: The legal relationship between the proposed UNIDROIT Convention and its equipment - specific Protocols. „Revue de droit uniforme”, „Uniform Law Review” 1999, 2.

Drozd E.: Nabycie i utrata praw rzeczowych na rzeczy ruchomej w prawie prywatnym międzynarodowym (wpływ zmiany miejsca położenia rzeczy na właściwość prawa). Kraków 1977.

Foëx B.: La réserve de propriété dans l'avant - projet de Convention d'UNIDROIT: un point de vue suisse. „Revue de droit uniforme”, „Uniform Law Review" 1999, 2.

Goode R.: A Credit Law for Europe? „International and Comparative Law Quarterly" 1974, vol. 23.

Goode R.: The Cape Town Convention on International Interests in Mobile Equipment: a Driving Force for International Asset - Based Financing. „Revue de droit uniforme”, „Uniform Law Review” 2002, 1.

Goode R.: The preliminary draft UNIDROIT Convention on International Interests in Moblie Equipment: the next stage. „Revue de droit uniforme”, „Uniform Law Review" 1999, 2. 
Goode R., Drobnig U.: Security for Payment in Export and Import Transactions. In: Commercial Operations in Europe. Eds. K. Simmonds, R. Goode. London 1978.

Gopalan S.: Securing Mobile Assets: The Cape Town Convention and Its Aircraft Protocol. „North Carolina Journal of International Law and Commercial Regulation" 2003, vol. 29.

Górecki J.: Komentarz do art. 41. W: Prawo prywatne międzynarodowe. Komentarz. Red. M. Pazdan. Warszawa 2018.

Haase V.: Entwicklung der Verkäufersicherungsrechte an beweglichen Sachen in Frankreich. Frankfurt am Main 2001.

Heß K.P.: Der Eigentumsvorbehalt und die Sicherung von „all - sums - clauses” in englischen und schottischen Recht. „Recht des Internationalen Wirtschaft" 1991, H. 9.

Juvet I.: Des sûretés mobilières conventionelles en droit international privé. Bern-Franfurt am Main-New York-Paris 1990.

Kessel Ch.: Eigentumsvorbehalt und Rezession in Grossbritannien. „Recht des Internationalen Wirtschaft" 1991, H. 10.

Khairallah G.: Les sûretés mobilières en droit international privé. Paris 1984.

Kieninger E.M.: Mobiliarsicherheiten in Europäischen Binnenmarkt. Baden-Baden 1996.

Kieninger E.M., in: Security Rights in Movable Property in European Private Law. Ed. E.M. Kieninger. Cambridge 2004.

Kosik J.: Zagadnienia prawa rzeczowego $w$ prawie prywatnym międzynarodowym z 1965 r. Warszawa-Wrocław 1967.

Kozioł A., Zrałek J., w: Prawo prywatne międzynarodowe. Komentarz. Red. M. Pazdan. Warszawa 2018.

Kozioł A., Zrałek J., w: „System Prawa Prywatnego”. T. 20C: Prawo prywatne międzynarodowe. Red. M. Pazdan. Warszawa 2015.

Kunicki A.: Skutki prawne zastrzeżenia własności. „Ruch Prawniczy, Ekonomiczny i Socjologiczny" 1967, z. 2.

Lißner S., Zwernemann D.: Eigentumsvorbehalt im internationalen Handel. In: Handbuch für Kaufrecht. Rechtsdurchsetzung und Zahlungssicherung im Außenhandel. Hrsg. S.G. Häberle. München-Wien 2002.

Looschelders D.: Internationales Privatrecht. Art. 3-46 EGBGB. BerlinHeidelberg 2004.

Loussouarn Y.: Les conflits de lois en matière de réserve de propriété. In: Études offertes à Roger Houin. Problèmes d'actualité posés par les entreprises. Paris 1985.

Loussouarn Y.: Les conflits de lois en matière de réserve de proprieté. Travaux du comité français de droit international privé. Séance du 18 mai 1983 sous présidence de Henri Batiffol. In: Droit International Privé. Années 19821983. Paris 1986.

Maаß M.J.: Die Gesischte des Eigentumsvorbehaltes, insbesondere im 18. und 19. Jahrhundert. Frankfurt am Main 2000. 
Margellos T.M.: La protéction du vendeur à crédit des objets mobilières à travers la clause de réserve de propriété (Étude de droit comparé). Paris 1989.

Marlow J., Weber-Rey D.: Retention of title clauses in Germany. „International Company and Commercial Law Review" 1994, no. 5.

Mestre J., Pancraz i M.-E.: Droit Commercial. Droit interne et aspects de droit international. Paris 2009.

Mik C., Wojtaszek-Mik E.: Zwalczanie opóźnień $w$ płatnościach $w$ transakcjach handlowych $w$ świetle dyrektywy 2000/35/WE i prawa polskiego. „Zeszyty Prawnicze UKSW” 2000, z. 3.

Milo J.: Retention of Title in European Business Transactions. „Washburn Law Journal" 2003, no. 3.

Naumann K.: Der Eigentumsvorbehalt im deutsch-italienischen Rechtsverkehr. Frankfurt am Main-Bern-Bruxelles-New York-Oxford-Wien 2001.

Panahy D.A., Mittal R.: The prospective UNIDROIT Convention on international interests in mobile equipment as applied to space property. „Revue de droit uniforme”, „Uniform Law Review” 1999, 2.

Pazdan J.: Komentarz do art. 25, w: Prawo prywatne międzynarodowe. Komentarz. Red. M. Pazdan. Warszawa 2018.

Pazdan M.: Prawo prywatne międzynarodowe. Warszawa 2017.

Pazdan M., w: „System Prawa Prywatnego”. T. 20A: Prawo prywatne międzynarodowe. Red. M. Pazdan. Warszawa 2014.

Pérochon F.: La réserve de priopriété dans la vente de meubles corporels. Paris 1988.

Podhorecka M.: Skutki prawne zastrzeżenia prawa własności w obrocie międzynarodowym. Wybrane zagadnienia. "Kwartalnik Prawa Prywatnego" 2006, z. 1.

Reisinger R.: Der Eigentumsvorbehalt im österreichischen und englischen Recht unter Berücksichtigung des österrichischen und englischen Kollisionsrechtes und der internationalen Zuständigkeit. Wien 2002.

$\mathrm{R}$ os en H.: Creating an international security structure for railway rolling stock: an idea ahead of its time? „Revue de droit uniforme”, „Uniform Law Review” 1999, 2.

Rutgers J.W.: International Reservation of Title Clauses. A study of Dutch, French and German International Law in the Light of European Law. The Hague 1999.

Sandoz S.: L’inscription du pacte de réserve de propriété: une solution „génia$l e ” .$. diabolique. „Revue de droit Suisse” / „Zeitschrift für Schweizerisches Recht" 1987, 1.

Schulz M.: Der Eigentumsvorbehalt in europäischen Rechtsordnungen. Rechtvergleichende Untersuchung des deutschen, englischen und französischen Rechts unter besonderer Berücksischtigung von Erweiterungen und Verlängerungen. Frankfurt am Main-Bern-New York-Paris-Wien 1998.

Spellenberg U.: Eigentumsvorbehalt in Frankreich. „Zeitschrift für Rechtsvergleichung, Internationales Privatrecht und Europarecht” 1994, H. 3. 
Storp R.: Eigentumsvorbehalt und Aussonderungsverfahren nach der Reform des französichen Insolvenzrecht. „Recht des Internationalen Wirkschaft” 1996, H. 6.

Strauch J.: Der Eigentumsvorbehalt bei Warenlieferungen in das Ausland. Die Regelungen in wichtigen Exportländern. Offenbach am Main 1997.

Sznajder-Peroń K., w: Prawo prywatne międzynarodowe. Komentarz. Red. M. Pazdan. Warszawa 2018.

Sznajder-Peroń K., w: „System Prawa Prywatnego”. T. 20A: Prawo prywatne międzynarodowe. Red. M. Pazdan. Warszawa 2014.

Szpunar A.: Zastrzeżenie własności rzeczy sprzedanej. „Państwo i Prawo” 1993, z. 6.

Ziegler von A., Debattista Ch., Plégat O.: Transfer of Ownership in International Trade. The Hague 2010.

Żmij G.: Prawo waluty. Kraków 2012. 